\title{
GUERNICA Y LA LUCHA CONTRA LA OPRESIÓN EN EL POETA TUNECINO AHMAD QADIDI
}

\author{
Por \\ M. ${ }^{a}$ JESÚS RUBIERA MATA \\ ROCIO LLEDÓ
}

La guerra civil española se vió en Túnez, como en Argelia a través de una óptica particular que pasaba indudablemente por el hecho colonial y por tanto por el filtro de Francia. En general, los grupos de izquierdas, como en Francia, eran partidarios de la República. Pero estas simpatías, estaban matizadas, excepto para los comunistas, por un profranquismo que era consecuencia de las promesas del general a los marroquies de concederles la autonomía cuando acabase el conflicto. Promesas que contrastaban con una época de colonialismo francés muy duro (1).

El final de la guerra civil no mejoró las cosas, ya que los exiliados españoles fueron discriminados por las autoridades y encerrados en campos de concentración, aterrorizando a las clases populares norteafricanas sobre su presencia que iba a quitar el trabajo a los tunecinos. Del terrible exilio norteafricano de los republicanos se hablará en otras de las comunicaciones de este congreso (M. de Epalza, Max Aub y los escritores españoles exiliados en Argelia). La guerra mundial y su postguerra empeoraron la situación, ya que el conflicto de Palestina, ayudó a que Franco tuviese "buena imagen» entre los árabes, la cual se perpetuó hasta su muerte.

El conocimiento de la realidad española durante el franquismo fue tampoco favorable a un cambio de esta actitud norteafricana; a nivel intelectual, los escritores norteafricanos no veían una realidad social peor que la propia

(1) Abdelhakim El Gafsi, De Cartagena a Bizerta. Prolongaciones tunecinas de la guerra civil española (19361939). Anales de Historia Contemporánea, Murcia 1983, II, pp. 251-261. 
y en España les guiaba siempre el mito de al-Andalus, singularmente vivo en Túnez donde una parte de la población era descendiente auténtica o pretendida, de los moriscos expuisados de España. De ahí que de nuevo el posible republicanismo de los escritores tunecinos debe ir mediatizado por Francia.

Éste es el caso del escritor que nos ocupa. Es indudable que el republicanismo de Ahmad Qadidi procede más de su formación francesa que de sus raíces árabes.

Este autor, nacido en Kairawan en 1946 conoce a través de Europa a los grandes mitos literarios españoles no andalusies, por ejemplo a Federico García Lorca y así, sorprendentemente en un escritor árabe, al recorrer de noche las tierras hispánicas, en un tren, en compañía de una mujer española, silenciosa viajera en su comportamiento, no le vienen al recuerdo los amores de Wallāda y de Ibn Zaydūn, los amantes cordobeses del siglo XI, ni Rumaykiyya y al-Mu tamid, sino Lorca, al que imagina tallando letras, asesinado (2). Y su pensamiento le lleva a Madrid, no a Córdoba ni a Granada, sino a un Madrid dominado por el absurdo que olvidará en una noche de flamenco.

También a través de su formación europea llegará a Picasso y con motivo de la muerte del pintor escribe un poema sobre Guernica, sobre la ciudad destruida, en el que alude a los Guernicas árabes.

Este poema fue publicado en la revista tunecina al-Fikr en 1973. No imaginaba aquel año que su poema iba a estar de nuevo de actualidad en 1985. Tanto es así que ha sido editado de nuevo por la revista al-Sirr. La razón es que la tragedia de Guernica se ha encarnado en la piel de una ciudad tunecina. Un día, sin provocación, sin guerra, el ejército israeli bombardea una ciudad tunecina, bajo en pretexto de que allí se encuentra Yasser Arafat. Niños tunecinos mueren ignorantes de que van a ser hermanos de aquellos niños vascos.

(2) La presencia de Lorca en la literatura árabe ha sido analizada por P. Martínez Montávez en su estudio "Presencia de Federico García Lorca en la literatura árabe actual» publicado en las Actas do IV Congresso d'Estudos Arabes e Islámicos. Coimbra, 1968, Leiden. 
GUERNICA ÁRABE (Garnica al- arabiyya)

(elegía personal a la muerte del pintor Picasso)

por Ahmad Qadidi

(Revista «al-Fikr», Túnez, junio 1973)

Cayó Guernica

en manos de fascistas, y murió el alba azul.

Inútilmente esperas

la salida del sol,

Señora de amplios ojos,

inútilmente.

$Y$ el mundo se queda sin palabras,

y la historia queda bloqueada por los torturadores,

piratas del amor,

asesinos de la libertad.

Inútilmente,

te quedas desnuda frente al mar, que el mar ni comprende, ni ama, mientras arden los niños y el poeta arde.

Sigue habiendo Guernicas en mi tierra árabe, cayendo, derrumbándose.

Y siguen los revolucionarios

invadiendo los campos de concentración, cargándose al mundo una y otra vez. construyendo para los hijos de los pobres ciudades de libertad.

Golpea aus pies contra la tierra española.

Esta danza que rechaza a la muerte

es una llamada a la revolución, a los hombres libres.

Golpea con tus pies,

que Guernica ya cayó, jay, gitana!

Este poema ha sido traducido por el doctor Míkel de Epalza UUniversidad de Alicante).

Terminamos esta breve comunicación con la trađucción del poema ya mencionado al referinos a García Lorca. 
A una amiga española

que encontré en el tren Ginebra-Madrid en un viaje nocturno

Amiga mía,

no abras tus ojos si quieres dormir:

la noche sigue negra de tinieblas;

la noche sigue

y sigue Madrid en manos del absurdo.

Amiga mía,

da a tus pupilas sosiego y paz,

pues yo he encontrado en ti la fuente de la belleza

y no hay sueño para mí;

soy un vagabundo al que conoce el insomnio,

al que conocen las grandes calles.

No importa que duermas

así puedo vivir la languidez del ardor.

¿Sigues deseando la compañía del insomnio?

Ven, mira la prodigiosa lluvia

sobre las llanuras y los montes

y sobre el río Ródano.

Deseo verte mirando la lluvia

y soñando

pues nosotros poseemos la naturaleza de la ilusión

y somos hijos de la inquietud.

España duerme en tus ojos y las arenas

en mi patria adorada son infinitas.

Sus horizontes se dibujan ante ti

ante la negrura, en tus ojos.

Princesa mía,

somos dos semejantes perdidos

$y$ hay un tercero: la angustia

y un cuarto: el dolor

"Lorca" su collar es una hoja afilada

pero yo lo veo

y escucho balas en Madrid

como si hubiese vencido, joh, amiga mía!, al tiempo

y vuelvo

y vuelvo huyendo hacia atrás

y acudo a Lorca, cuando tallaba letras

y construía belleza y poder.

Perdona, amiga mía,

despojado de ardor

despojado de pasión

por un mundo lejano.

No importa, entorna de nuevo tus ojos 
$y$ dormirás

mientras el tren se desliza rápido a Madrid.

Cuando llegues joh mi princesa!, allí, lleva mis saludo a los negros ojos a las guitarras de cuerdas calientes en el baile flamenco

allí en Madrid, tras dos o tres horas me habré apeado en una estación sin identidad porque yo quiero ser un vagabundo sin identidad. 